\title{
Effect of Planting Geometry and Seed Treatment on Growth and Yield of Wheat (Triticum aestivum L.) under System of Wheat Intensification
}

\author{
M. Haque ${ }^{1}$, A. Roy Chowdhury ${ }^{1 *}$, S. S. Acharya ${ }^{1}$, M. Ghosh ${ }^{1}$, Sanjay Kumar $^{1}$ and Nikhil Kumar ${ }^{1}$ \\ ${ }^{1}$ Dept. of Agronomy, Bihar Agricultural University, Sabour, Bhagalpur, Bihar (813 210), India
}

\section{Article History}

Manuscript No. AR1358

Received in $28^{\text {th }}$ March, 2015

Received in revised form $18^{\text {th }}$ May, 2015

Accepted in final form $4^{\text {th }}$ June, 2015

\section{Correspondence to}

"E-mail: arnabuas@gmail.com

\section{Keywords}

Planting geometry, seed treatment, SWI, wheat

\begin{abstract}
A field experiment was conducted during rabi season of 2011-12 and 2012-13 at Bihar Agricultural college, Sabour, Bhagalpur, Bihar, to study the effect of planting geometry and seed treatment on growth and yield of wheat under System of Wheat Intensification. The results indicated that maximum grain yield of wheat i.e., 48.71 and 51.17 $\mathrm{q} \mathrm{ha}^{-1}$ during 2011-12 and 2012-13, respectively were recorded when the crop was sown in a fashion of $15 \times 15 \mathrm{~cm}^{2}$ planting geometry which was significantly higher than the grain yield recorded under conventional and $10 \times 10 \mathrm{~cm}^{2}$ planting geometry but was at par with that obtained under the $20 \times 20 \mathrm{~cm}^{2}$ planting geometry. It was also observed that grain yield of wheat was significantly higher with treated seeds i.e., 44.55 and $47.41 \mathrm{q} \mathrm{ha}^{-1}$ during 2011-12 and 2012-13 respectively, as compared to that obtained with untreated seed. With respect to grain yield, the treatment $15 \times 15 \mathrm{~cm}^{2}$ geometry registered highest \% increment in grain yield, having values $16.6 \%$ and $14.8 \%$ followed by $20 \times 20 \mathrm{~cm}^{2}$ with values $11.4 \%$ and $7.7 \%$ in $2011-12$ and $2012-13$ respectively, over conventional sowing, the $\%$ increase in $\mathrm{B}: \mathrm{C}$ ratio also followed the same trend during both the years of experimentation.
\end{abstract}

\section{Introduction}

Worsening of primary resources and excessive use of agrochemicals to increase the production become a threat to the environment. It is very necessary to meet the future need for food, feed and fuel without excessive resource use. Wheat is the main field crop in many temperate and subtropical areas (Rasmussen et al., 2015) and efficient use of primary resources is of high concern. Wheat crop plays a pivotal role in India's food security after rice. In India, wheat occupies an area of 29.65 million ha with the production of 92.46 million $\mathrm{t}$, contributing $36 \%$ of the total food grain production (Anonymous, 2013). The low productivity of wheat in India is mainly due to delayed sowing, short winter, application of input at right time at right place and terminal heat particularly in North Eastern Plain Zone of India, leading to shy tillering, inadequate crop establishment and shrivelled grains. Traditionally, wheat is grown by broadcasting and continuously sowing of seeds in line without maintaining any specific planting geometry, which have been served well for long tracts but the limitations like non uniformity in crop stand leads to dilution effect of input and reflects in crop yield. System of Wheat Intensification (SWI) is a technique of wheat production which is based on manipulation of soil environment with minimum external inputs and very low seed rate. SWI is based on the principles of system of rice intensification in a new cultivation technique which demands to maintain optimum plant population, allowing sufficient aeration, moisture, sunlight and nutrient availability, leading to proper root system development for early stage of crop growth. SWI is a synergistic management technique involving components of wheat farming such as planting less number of seeds per hill with wider spacing and seed treatment with specific organic formulations like vermicompost, cow urine and jaggery, along with carbendazim. The management practices under SWI provide better conditions for growth of wheat crop due to greater proliferation of root hair and root length than those grown under traditional wheat farming. Seed treatment also plays an important role in early germination of seedling in SWI. SWI enhances the grain yield to the tune of $20-25 \%$ over that of conventional sowing (ATMA, 2008). Khadka and Raut (2011) reported positive response of seed priming and line sowing in wheat crop over conventional practice. However, a very little information regarding the effect of SWI technique on growth and productivity of wheat is available. Therefore, the 
present experiment was conducted to investigate the effect of planting geometry coupled with seed treatment on the growth and productivity of wheat under SWI.

\section{Materials and Methods}

A field experiment was conducted during rabi season of 2011-12 and 2012-13 at Bihar Agricultural College, Sabour, Bhagalpur, Bihar, to study the effect of planting geometry and seed treatment on growth and productivity of wheat under SWI. Bihar Agricultural College, Sabour is situated at a longitude of $87^{\circ} 2^{\prime} 42^{\prime \prime} \mathrm{E}$, latitude of $25^{\circ} 15^{\prime} 40^{\prime \prime} \mathrm{N}$ and at an altitude of 46 meters above mean sea level in the heart of the vast Indo-Gangetic plains of North India. The climate of this place is tropical to subtropical and is characterized by very dry summer, moderate rainfall and very cold winter. December and January are usually the coldest months where the mean temperature normally falls as low as $8.2^{\circ} \mathrm{C}$. However, the mean temperature varied between 30.2 to $11.2{ }^{\circ} \mathrm{C}$ and 28.4 to $9.75^{\circ} \mathrm{C}$ during the experimentation of $2011-12$ and $2012-$ 13 respectively. The crops received a total of $27.7 \mathrm{~mm}$ and $94.5 \mathrm{~mm}$ rainfall during the two consecutive rabi seasons respectively. The soil of the experimental plot was sandy loam in texture ( $49.01 \%$ sand, $36.6 \%$ silt and $13.6 \%$ clay), neutral in reaction $(\mathrm{pH}=7.45)$, medium in organic carbon $(0.55 \%)$, low in available $\mathrm{N}\left(157 \mathrm{~kg} \mathrm{ha}^{-1}\right)$ and medium in available $\mathrm{P}(22.40$ $\left.\mathrm{kg} \mathrm{ha}^{-1}\right)$ and $\mathrm{K}\left(162 \mathrm{~kg} \mathrm{ha}^{-1}\right)$.

The experiment was laid out in split plot design replicated four times. The planting geometry treatments like conventional i.e., row-row distance of $23 \mathrm{~cm}$ with continuous sowing $\left(\mathrm{P}_{1}\right)$, $10 \times 10 \mathrm{~cm}^{2}\left(\mathrm{P}_{2}\right), 15 \times 15 \mathrm{~cm}^{2}\left(\mathrm{P}_{3}\right)$ and $20 \times 20 \mathrm{~cm}^{2}\left(\mathrm{P}_{4}\right)$ were taken in main plot and the seed treatments like treated seed $(\mathrm{T})$ and untreated seed (UT) were taken in sub plot. For seed treatment, $10 \mathrm{~kg}$ seed of wheat were poured in 20 litres of hot water with $2.25 \mathrm{~kg}$ vermicompost, $1100 \mathrm{~g}$ jaggery and 4 litre cow urine and kept for 8 hours. Seed mixture was separated from the solution and treated with $4 \mathrm{~g}$ carbendazim per $\mathrm{kg}$ seed. Treated seeds were kept in wet jute bag for 8-10 hours and were then dried in shade for about an hour. The wheat variety for timely sown irrigated condition i.e., HD 2733 was used in the eperiment. A seed rate of $100 \mathrm{~kg} \mathrm{ha}^{-1}$ in conventional sowing, $80 \mathrm{~kg} \mathrm{ha}^{-1}$ in $10 \times 10 \mathrm{~cm}^{2}, 34 \mathrm{~kg} \mathrm{ha}^{-1}$ in $15 \times 15 \mathrm{~cm}^{2}$ and $20 \mathrm{~kg} \mathrm{ha}^{-1}$ in $20 \times 20 \mathrm{~cm}^{2}$ planting were used. All the plots were fertilized with a fertilizer dose of 120:60:40 kg N: $\mathrm{P}_{2} \mathrm{O}_{5}: \mathrm{K}_{2} \mathrm{O}$ ha $^{-1}$. Half of the $\mathrm{N}$ and full $\mathrm{P}$ and $\mathrm{K}$ were applied as basal and remain $\mathrm{N}$ were applied in 2 equal splits after 25 and 50 days after sowing (DAS). Four irrigations were given at 25, 50, 75 and 85 DAS.

The observation on growth parameters like plant height and leaf area index (LAI) were recorded at 30, 60 and 90 DAS, whereas, number of tillers $\mathrm{m}^{-2}$ was worked out at $60 \mathrm{DAS}$. For
LAI, leaves were separated from the plants, treatment wise and kept in paper packets which were then dried by placing the packets in a hot air oven at a temperature of $60^{\circ} \mathrm{C}$ till constant weight were reached. The dry weight of leaves was used for determining LAI as suggested by Watson (1952). Various yield parameters like numbers of earhead $\mathrm{m}^{-2}$, numbers of grains earhead $^{-1}$, test weight along with grain yield were recorded at maturity. The data thus obtained were statistically analyzed as per procedure of analysis of variance technique and the significance of different source of variations were tested by error mean square of Fischer's $F$ test at probability level 0.05 (Cochran and Cox, 1977). The economics of the experiment was calculated and analyzed by taking market price of inputs and produces for the respective years of experimentation.

\section{Results and Discussion}

\subsection{Effect of planting geometry on growth attributes of wheat}

Growth parameters like plant height, number of tillers $\mathrm{m}^{-2}$ and LAI were found to be significantly influenced by different planting geometry and seed treatment during both the years of experimentation. At 30 DAS, the plant height was not significantly influenced by planting geometry, whereas, at 60 and 90 DAS, the plant height was significantly influenced, with the highest value recorded for $20 \times 20 \mathrm{~cm}^{2}$ geometry, which was in turn statistically at par with that recorded under $15 \times 15 \mathrm{~cm}^{2}$ planting geometry (Table 1). It was also revealed that in all the cases, plant height under $20 \times 20 \mathrm{~cm}^{2}$ and $15 \times 15 \mathrm{~cm}^{2}$ were higher than the conventional sowing of wheat which might be due to the fact that wider spacing decreased competition among plants for light, water, space and nutrients due to higher light interception, root distribution and nutrient availability that play important role in plant growth (Tej Thapa et al., 2011; Thakur et al., 2010). Similar type of result was also obtained by Mondal et al. (2013) in West Bengal. Likewise, maximum number of tillers $\mathrm{m}^{-2}$ i.e., 277 and 285 respectively, during 2011-12 and 2012-13 were recorded from the treatment $15 \times 15$ $\mathrm{cm}^{2}$ geometry and was in turn significantly superior to the rest of the planting geometries except $20 \times 20 \mathrm{~cm}^{2}$.

The LAI of 4.17 and 4.55 during 2011-12 and 2012-13, respectively at 60 DAS and 5.67 and 5.91 during 2011-12 and 2012-13, respectively at 90 DAS, were recorded from the treatments of $15 \times 15 \mathrm{~cm}^{2}$ and was in turn significantly superior to the rest of the planting geometries except the $20 \times 20 \mathrm{~cm}^{2}$ geometry. This might be due to the fact that wider spacing under SWI technique facilitated optimum plant population per unit area and leaf area per plant which might have contributed to the maximum values of tillers per square meter and LAI in the treatments under $15 \times 15 \mathrm{~cm}^{2}$. This is in conformity with result of Thakur et al. (2010). 


\subsection{Effect of seed treatment on growth attributes of wheat}

The seed treatment significantly influenced the plant height, tillers $\mathrm{m}^{-2}$ and LAI at all the growth stages in comparison to untreated with higher values recorded under treated condition. This profound effect of seed treatment with the specific organic formulation on all the growth attributes of the crop has been attributed due to the fact that cow urine contains physiologically active substances viz., growth regulators, nutrients and trace elements (Kamalam and Rajappan, 1989). Dell-Aquila and Tritto (1990) also supported the findings of this study through their reports whereby they documented increased activity of enzymes such as amylase, protease and lipase which have great role in breakdown of micro molecules for growth and development of embryo that ultimately resulted in early and higher growth of seedlings of wheat.

\subsection{Effect of planting geometries and seed treatment on yield components of wheat}

Different planting geometry significantly influenced the yield contributing characters viz. earhead $\mathrm{m}^{-2}$, grains earhead ${ }^{-1}$ and 1000 seed weight (Table 2). Maximum number of earhead $\mathrm{m}^{-2}$ i.e., 275.8 and 281.6 during 2011-12 and 2012-13 respectively and 1000 seed weight $39.0 \mathrm{~g}, 39.5 \mathrm{~g}$ during 2011 12 and 2012-13 respectively, were recorded under $15 \times 15 \mathrm{~cm}^{2}$ planting geometry and was found to be significantly superior to conventional sowing and $10 \times 10 \mathrm{~cm}^{2}$ but was at par with $20 \times 20 \mathrm{~cm}^{2}$ planting geometry. The increase in earhead $\mathrm{m}^{-2}$ under SWI with wider spacing was due to production of more number of effective tillers. Kanakadurga (2012) also reported that wider spacing facilitates plants for better utilization of nutrient, water, light and space leading to produced maximum number of effective tillers per unit area than conventional practices. With respect to grains earhead ${ }^{-1}$, maximum number i.e., 42.63 and 45.13 during 2011-12 and 2012-13, respectively, were obtained from $20 \times 20 \mathrm{~cm}^{2}$ planting geometry and was found to be at par with values of 42.38 and 44.50 during 2011-12 and 2012-13, respectively, recorded under $15 \times 15$ $\mathrm{cm}^{2}$ planting geometry. Effect of Seed treatment on yield components was also found to be significant during both the years in comparison to untreated.

\subsection{Effect of planting geometries and seed treatment on grain yield of wheat}

Significant influence of planting geometry on grain yield was also recorded during both the years of experimentation. Maximum grain yield of 48.71 and $51.17 \mathrm{q} \mathrm{ha}^{-1}$ was recorded during 2011-12 and 2012-13, respectively under $15 \times 15 \mathrm{~cm}^{2}$ planting geometry and was found to be significantly superior to conventional sowing and $10 \times 10 \mathrm{~cm}^{2}$ geometry but was at par with $20 \times 20 \mathrm{~cm}^{2}$. This was due to maximum number of earhead $\mathrm{m}^{-2}, 1000$ seed weight and grains earhead ${ }^{-1}$ of the crop observed under the planting geometry $15 \times 15 \mathrm{~cm}^{2}$. Besides, a significantly increasing trend was recorded in grain yield of wheat under wider spacing upto $15 \times 15 \mathrm{~cm}^{2}$ and decreased further in $20 \times 20 \mathrm{~cm}^{2}$ during both the years. This was mainly due to the fact that wider spacing of $20 \times 20 \mathrm{~cm}^{2}$ recorded lesser plant population and productive tillers resulting in decrease in number of ear head per unit area. This was in conformity with the finding of Jayawardena and Abeysekera (2011) and Thakur et al. (2010).

\begin{tabular}{|c|c|c|c|c|c|c|c|c|c|c|c|c|c|c|}
\hline \multirow[t]{4}{*}{ Treatments } & \multicolumn{6}{|c|}{ Plant height $(\mathrm{cm})$} & \multirow{2}{*}{\multicolumn{2}{|c|}{$\begin{array}{l}\text { Tiller } \mathrm{m}^{-2} \\
(60 \mathrm{DAS})\end{array}$}} & \multicolumn{6}{|c|}{ LAI } \\
\hline & \multicolumn{3}{|c|}{$2011-12$} & \multicolumn{3}{|c|}{$2012-13$} & & & \multicolumn{3}{|c|}{$2011-12$} & \multicolumn{3}{|c|}{ 2012-13 } \\
\hline & 30 & 60 & 90 & 30 & 60 & 90 & $2011-$ & $2012-$ & 30 & 60 & 90 & 30 & 60 & 90 \\
\hline & DAS & DAS & DAS & DAS & DAS & DAS & 12 & 13 & DAS & DAS & DAS & DAS & DAS & DAS \\
\hline \multicolumn{15}{|c|}{ Planting geometry } \\
\hline $\mathrm{P}_{1}$ & 24.2 & 44.4 & 91.8 & 24.9 & 45.6 & 93.3 & 251 & 260 & 0.61 & 3.47 & 4.54 & 0.62 & 3.87 & 5.21 \\
\hline $\mathrm{P}_{2}$ & 23.6 & 41.4 & 85.6 & 24.4 & 42.3 & 86.8 & 236 & 244 & 0.60 & 3.07 & 3.53 & 0.61 & 3.24 & 4.12 \\
\hline $\mathrm{P}_{3}$ & 25.3 & 47.9 & 98.8 & 25.7 & 47.9 & 101.1 & 277 & 285 & 0.59 & 4.17 & 5.67 & 0.59 & 4.55 & 5.91 \\
\hline $\mathrm{P}_{4}$ & 25.7 & 48.0 & 98.9 & 25.9 & 48.3 & 100.8 & 267 & 276 & 0.58 & 4.13 & 5.59 & 0.59 & 4.50 & 5.80 \\
\hline $\operatorname{SEm} \pm$ & 0.49 & 1.02 & 1.41 & 0.33 & 0.88 & 1.35 & 3.47 & 3.02 & 0.007 & 0.21 & 0.22 & 0.01 & 0.17 & 0.17 \\
\hline $\mathrm{CD}(p=0.05)$ & NS & 3.28 & 4.52 & NS & 2.82 & 4.32 & 11.11 & 9.68 & 0.02 & 0.67 & 0.72 & 0.04 & 0.53 & 0.55 \\
\hline \multicolumn{15}{|l|}{ Seed treatment } \\
\hline $\mathrm{T}$ & 25.4 & 46.8 & 96.2 & 26.3 & 47.2 & 98.2 & 261 & 271 & 0.60 & 3.87 & 5.15 & 0.61 & 4.30 & 5.58 \\
\hline UT & 24.0 & 44.1 & 91.4 & 24.2 & 44.8 & 92.8 & 254 & 261 & 0.59 & 3.54 & 4.52 & 0.59 & 3.77 & 4.94 \\
\hline $\mathrm{SEm} \pm$ & 0.19 & 0.18 & 0.20 & 0.15 & 0.20 & 0.24 & 0.40 & 0.55 & 0.004 & 0.03 & 0.06 & 0.004 & 0.06 & 0.05 \\
\hline $\mathrm{CD}(p=0.05)$ & 0.58 & 0.55 & 0.62 & 0.47 & 0.63 & 0.74 & 1.24 & 1.70 & 0.01 & 0.09 & 0.20 & 0.01 & 0.19 & 0.17 \\
\hline
\end{tabular}

$\mathrm{P}_{1}$ : Conventional sowing; $\mathrm{P}_{2}: 10 \times 10 \mathrm{~cm}^{2} ; \mathrm{P}_{3}: 15 \times 15 \mathrm{~cm}^{2} ; \mathrm{P}_{4}: 20 \times 20 \mathrm{~cm}^{2}$; T: Treated seed; UT: Untreated seed 
With respect to $\%$ increment in grain yield, the treatment $15 \times 15 \mathrm{~cm}^{2}$ geometry registered highest values of $16.6 \%$ and $14.8 \%$ followed by $20 \times 20 \mathrm{~cm}^{2}$ having values, $11.4 \%$ and $7.7 \%$ respectively, over conventional sowing, during the consecutive years of experimentation (Figure 1).

Seed treatment also imparted positive influence on grain yield of wheat during both the years. Maximum grain yield of 44.55 and $47.41 \mathrm{q} \mathrm{ha}^{-1}$ was recorded during 2011-12 and 2012-13 respectively from the treatments of treated seeds and was found to be significantly superior to the grain yield obtained from untreated. Similar type of findings were also reported by Khadka and Raut (2011); Misra et al. (2002).

3.5. Interaction effect of planting geometries and seed treatment on yield attributes and grain yield of wheat

Interaction effect of different planting geometry and seed treatment on yield contributing characters and grain yield of wheat was found to be significant during both the years of experimentation (Table 3 ). Treated seeds dibbled in a fashion of $15 \times 15 \mathrm{~cm}^{2}$ planting geometry produced significantly higher earhead $\mathrm{m}^{-2}$ (280.5 and 291.0 during 2011-12 and 2012-13, respectively) than all other treatment combinations. The highest grains earhead ${ }^{-1}$ i.e., 43.8 and 46.0 during 2011-12 and $2012-13$, respectively was recorded under $20 \times 20 \mathrm{~cm}^{2}$ planting geometry along with seed treatment but was statistically at par with $15 \times 15 \mathrm{~cm}^{2}$ geometry with seed treatment, with values 43.0 and 45.0 during 2011-12 and 2012-13, respectively. The highest grain yield of wheat (50.22 and $52.63 \mathrm{q} \mathrm{ha}^{-1}$ during 2011-12 and 2012-13, respectively) was recorded under $15 \times 15$ $\mathrm{cm}^{2}$ geometry with seed treatment which was statistically at par with the grain yield obtained from the treatment where treated seeds were sown in a fashion of $20 \times 20 \mathrm{~cm}^{2}$ planting geometry i.e., 47.94 and $50.13 \mathrm{q} \mathrm{ha}^{-1}$ during 2011-12 and 201213 , respectively but was significantly superior to that of the rest of the treatment combinations. The treated seeds along with $15 \times 15 \mathrm{~cm}^{2}$ geometry recorded $18 \%$ and $21 \%$ increase in grain yield during 2011-12 and 2012-13, respectively in comparison to treated conventional planting. This increase in grain yield might be due to the synergistic effect of seed treatment with bio-formulation along with optimum planting geometry.

\subsection{Economics}

Net return of wheat was significantly affected by planting geometry and seed treatments under SWI techniques during both the years of experimentation. Maximum net return of ₹ 46440 and ₹ 50835 during 2011-12 and 2012-13, respectively, was obtained under $15 \times 15 \mathrm{~cm}^{2}$ geometry with seed treatment, followed by $20 \times 20 \mathrm{~cm}^{2}$ geometry with seed treatment, during both the years and was higher than other treatment combinations (Table 4). The highest net returns, obtained in the above combination of treatments, were mainly due to higher economic yield. The results corroborated the findings of Suryawanshi et al. (2013).

The benefit cost ratio (B:C ratio) of wheat was also significantly affected by planting geometry under SWI techniques. Maximum B:C ratio of 1.68 and 1.69 during 2011-12 and 2012-13 respectively was obtained under $20 \times 20 \mathrm{~cm}^{2}$ geometry with seed treatment followed by $15 \times 15 \mathrm{~cm}^{2}$ geometry with seed treatment during both the years and were higher than other treatment combinations. The results corroborated the findings of Das and Choudhury (1996).

The $\%$ increase in $\mathrm{B}: \mathrm{C}$ ratio also followed the same trend

Table 2: Effect of planting geometries and seed treatment on yield attributing characters and grain yield (q ha-1) of wheat under SWI

\begin{tabular}{|c|c|c|c|c|c|c|c|c|}
\hline \multirow[t]{2}{*}{ Treatments } & \multicolumn{2}{|c|}{ Earhead $\mathrm{m}^{-2}$} & \multicolumn{2}{|c|}{ Grains earhead $^{-1}$} & \multicolumn{2}{|c|}{1000 seed weight $(\mathrm{g})$} & \multicolumn{2}{|c|}{ Grain yield $\mathrm{q} \mathrm{ha}^{-1}$} \\
\hline & $2011-12$ & $2012-13$ & $2011-12$ & $2012-13$ & $2011-12$ & $2012-13$ & 2011-12 & $2012-13$ \\
\hline \multicolumn{9}{|c|}{ Planting geometry } \\
\hline $\mathrm{P}_{1}$ & 248.3 & 256.0 & 41.38 & 43.38 & 37.4 & 38.5 & 41.76 & 44.57 \\
\hline $\mathrm{P}_{2}$ & 234.0 & 240.3 & 39.13 & 41.13 & 37.1 & 38.3 & 36.54 & 40.74 \\
\hline $\mathrm{P}_{3}$ & 275.8 & 281.6 & 42.38 & 44.50 & 39.0 & 39.5 & 48.71 & 51.17 \\
\hline $\mathrm{P}_{4}$ & 263.9 & 269.9 & 42.63 & 45.13 & 38.9 & 39.0 & 46.54 & 48.01 \\
\hline $\mathrm{SEm} \pm$ & 3.97 & 4.24 & 0.50 & 0.49 & 0.45 & 0.26 & 0.76 & 1.27 \\
\hline $\mathrm{CD}(p=0.05)$ & 12.71 & 13.56 & 1.59 & 1.57 & 1.44 & 0.83 & 2.44 & 4.05 \\
\hline \multicolumn{9}{|l|}{ Seed treatment } \\
\hline $\mathrm{T}$ & 258.7 & 266.3 & 42.19 & 44.25 & 38.8 & 39.3 & 44.55 & 47.41 \\
\hline UT & 252.3 & 257.6 & 40.56 & 42.81 & 37.4 & 38.4 & 42.22 & 44.83 \\
\hline $\mathrm{SEm} \pm$ & 0.41 & 1.26 & 0.14 & 0.13 & 0.18 & 0.13 & 0.13 & 0.22 \\
\hline $\mathrm{CD}(p=0.05)$ & 1.28 & 3.89 & 0.42 & 0.39 & 0.55 & 0.41 & 0.39 & 0.6 \\
\hline
\end{tabular}


Table 3: Interaction effect of planting geometries and seed treatment on yield attributes and grain yield (q ha $\left.{ }^{-1}\right)$ of wheat under SWI

\begin{tabular}{|c|c|c|c|c|c|c|c|c|c|}
\hline \multirow{2}{*}{$\begin{array}{l}\text { Planting } \\
\text { geometry }\end{array}$} & \multirow[t]{2}{*}{ Seed treatment } & \multicolumn{2}{|c|}{ Earhead $\mathrm{m}^{-2}$} & \multicolumn{2}{|c|}{ Grains earhead $^{-1}$} & \multicolumn{2}{|c|}{ Test weight $(\mathrm{g})$} & \multicolumn{2}{|c|}{ Grain yield $\left(\mathrm{q} \mathrm{ha}^{-1}\right)$} \\
\hline & & $2011-12$ & $2012-13$ & $2011-12$ & $2012-13$ & $2011-12$ & 2012-13 & 2011-12 & 2012-13 \\
\hline \multirow[t]{2}{*}{$\mathrm{P}_{1}$} & $\mathrm{~T}$ & 250 & 257 & 42.5 & 44.5 & 38.63 & 38.75 & 42.53 & 45.35 \\
\hline & UT & 247 & 255 & 40.3 & 42.3 & 36.25 & 38.25 & 41 & 43.79 \\
\hline \multirow[t]{2}{*}{$\mathrm{P}_{2}$} & $\mathrm{~T}$ & 237 & 244 & 39.5 & 41.5 & 37.50 & 38.3 & 37.53 & 41.55 \\
\hline & UT & 231 & 237 & 38.75 & 40.8 & 36.75 & 38.25 & 35.55 & 39.94 \\
\hline \multirow[t]{2}{*}{$\mathrm{P}_{3}$} & $\mathrm{~T}$ & 281 & 291 & 43 & 45 & 40.00 & 40.25 & 50.22 & 52.63 \\
\hline & UT & 271 & 272 & 41.8 & 44 & 38.00 & 38.75 & 47.21 & 49.71 \\
\hline \multirow[t]{2}{*}{$\mathrm{P}_{4}$} & $\mathrm{~T}$ & 267 & 274 & 43.8 & 46 & 39.13 & 39.75 & 47.94 & 50.13 \\
\hline & UT & 261 & 266 & 41.5 & 44.3 & 38.75 & 38.25 & 45.13 & 45.9 \\
\hline \multirow[t]{2}{*}{$\mathrm{P}$ at same $\mathrm{T}$} & $\mathrm{SEm} \pm$ & 4.02 & 4.6 & 0.53 & 0.52 & 0.51 & 0.32 & 0.78 & 1.3 \\
\hline & $\mathrm{CD}(p=0.05)$ & 12.37 & 14.17 & 1.63 & 1.6 & 1.58 & 0.98 & 2.41 & 4.01 \\
\hline \multirow[t]{2}{*}{$\mathrm{T}$ at same $\mathrm{P}$} & $\mathrm{SEm} \pm$ & 0.83 & 2.53 & 0.27 & 0.25 & 0.35 & 0.26 & 0.25 & 0.43 \\
\hline & $\mathrm{CD}(p=0.05)$ & 2.55 & 7.78 & 0.83 & 0.78 & 1.39 & 0.82 & 0.78 & 1.34 \\
\hline
\end{tabular}

$\mathrm{P}_{1}$ : Conventional sowing; $\mathrm{P}_{2}: 10 \times 10 \mathrm{~cm}^{2} ; \mathrm{P}_{3}: 15 \times 15 \mathrm{~cm}^{2} ; \mathrm{P}_{4}: 20 \times 20 \mathrm{~cm}^{2}$; T: Treated seed; UT: Untreated seed

\begin{tabular}{|c|c|c|c|c|c|c|c|c|c|}
\hline \multirow{2}{*}{$\begin{array}{l}\text { Planting } \\
\text { geometry }\end{array}$} & \multirow{2}{*}{$\begin{array}{c}\text { Seed } \\
\text { treatment }\end{array}$} & \multicolumn{2}{|c|}{ Gross income (₹ ha-1) } & \multicolumn{2}{|c|}{ Cost of cultivation (₹ $\left.\mathrm{ha}^{-1}\right)$} & \multicolumn{2}{|c|}{ Net income (₹ ha-1) } & \multicolumn{2}{|c|}{ B:C Ratio } \\
\hline & & 2011-12 & $2012-13$ & 2011-12 & $2012-13$ & $2011-12$ & $2012-13$ & $2011-12$ & $2012-13$ \\
\hline \multirow{2}{*}{$\mathrm{P}_{1}$} & $\mathrm{~T}$ & 63436.6 & 67439.8 & 26930 & 28968 & 36507 & 38472 & 1.36 & 1.33 \\
\hline & UT & 61220 & 67854.0 & 26235 & 28273 & 34985 & 39581 & 1.33 & 1.40 \\
\hline \multirow{2}{*}{$\mathrm{P}_{2}$} & $\mathrm{~T}$ & 56363.6 & 64426.5 & 31163 & 33801 & 25201 & 30626 & 0.81 & 0.91 \\
\hline & UT & 67821.4 & 61258.5 & 30635 & 33273 & 37186 & 27986 & 1.21 & 0.84 \\
\hline \multirow{2}{*}{$\mathrm{P}_{3}$} & $\mathrm{~T}$ & 74860.2 & 81487.5 & 28420 & 30653 & 46440 & 50835 & 1.63 & 1.66 \\
\hline & UT & 70182.4 & 76738.5 & 28185 & 29633 & 41997 & 47106 & 1.49 & 1.59 \\
\hline \multirow{2}{*}{$\mathrm{P}_{4}$} & $\mathrm{~T}$ & 71202.9 & 77524.5 & 26576 & 28872 & 44627 & 48653 & 1.68 & 1.69 \\
\hline & UT & 66917.1 & 70965.0 & 26435 & 28733 & 40482 & 42232 & 1.53 & 1.47 \\
\hline
\end{tabular}

$\mathrm{P}_{1}$ : Conventional sowing; $\mathrm{P}_{2}: 10 \times 10 \mathrm{~cm}^{2} ; \mathrm{P}_{3}: 15 \times 15 \mathrm{~cm}^{2} ; \mathrm{P}_{4}: 20 \times 20 \mathrm{~cm}^{2}$; T: Treated seed; UT: Untreated seed; 1 US $\$=$ ₹ 52.36 and ₹ 52.36 during March, 2012 and 2013, respectively

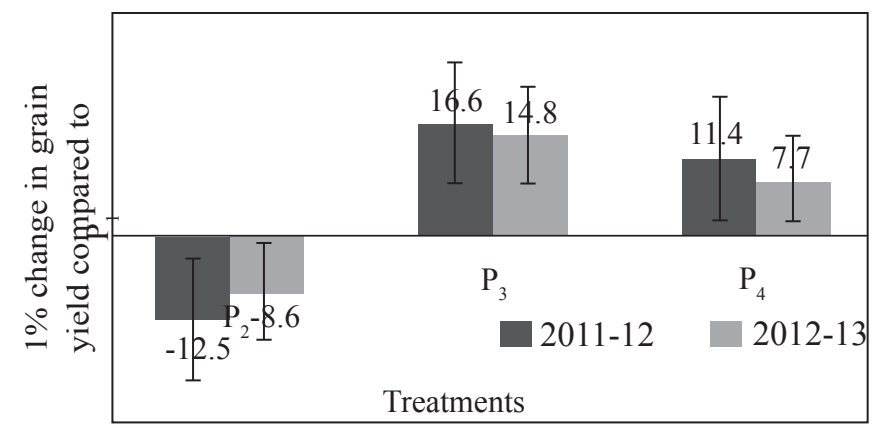

$\mathrm{P}_{1}$ : Conventional sowing; $\mathrm{P}_{2}: 10 \times 10 \mathrm{~cm}^{2} ; \mathrm{P}_{3}: 15 \times 15 \mathrm{~cm}^{2} ; \mathrm{P}_{4}: 20$

Figure 1: Percentage change in grain yield of wheat as influenced by planting geometry compared to conventional sowing

as that of grain yield, with highest values of $16.4 \%$ and $15.6 \%$ observed under $15 \times 15 \mathrm{~cm}^{2}$ geometry as compared to conventional sowing (Figure 2).

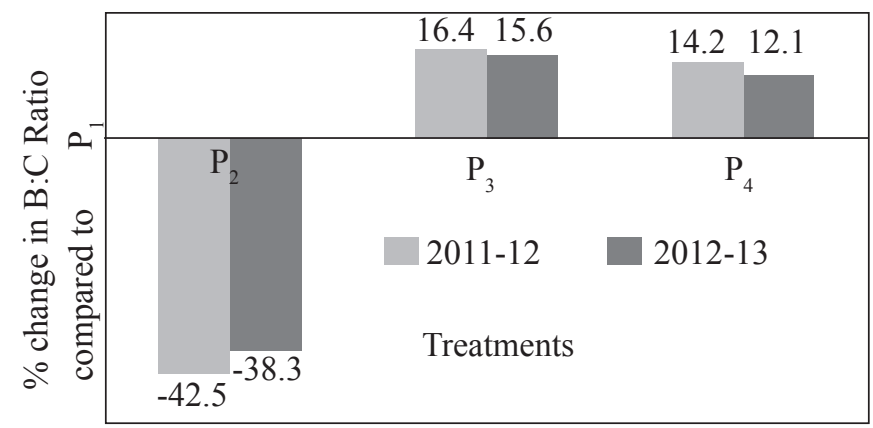

$20 \mathrm{~cm}^{2}$; The vertical line represents standard error of mean

Figure 2: Percentage change in B:C Ratio of wheat as influenced by planting geometry compared to conventional sowing

\section{Conclusion}

Raising wheat under SWI with a moderately closer planting geometry of $15 \times 15 \mathrm{~cm}^{2}$ and seed treatment with cow urine, 
vermicompost, jaggery and carbendazim optimised growth and yield attributes of wheat like plant population, earheads $\mathrm{m}^{-2}$ and 1000 grain weight, through efficient utilization of space, nutrients and moisture maintaining an edge over conventional technique, thereby enhancing the grain yield of wheat. The low input requirement of the technique can enhance economic benefit of the resource poor farmers.

\section{References}

Anonymous, 2013. Area, Production and yield of Principal Crops. Pocket Book of Agricultural Statistics. Directorate of Economics and Statistics, Department of Agriculture and Cooperation, Ministry of Agriculture, Government of India.

ATMA, 2008. Assessment, Refinement and validation of Technology through System of Wheat Intensification (SWI) in Nalanda. Final Report, krishi.bih.nic.in/SWI Final Report.pdf

Cochran, W.G., Cox, G.M., 1977. Experimental design. John Willy and Sons, New York, 640.

Dell-Aquila A., Tritto, V., 1990. Ageing and osmotic priming in wheat seeds. Effects upon certain components of seed quality. Annals of Botany 65, 21-26.

Jayawardena, S.N., Abeysekera, S.W., 2011. Effect of plant spacing on the yield of hybrid rice. Rice Research and Development Institute, Batalagoda, Ibbagamuwa.

Kamalam, J., Rajappan, N., 1989. Effect of seed hardening on germination and seedling vigour in paddy. Seed Research 17(2), 188-190.

Kanaka Durga, K., 2012. Influence of seedling age and spacing on productivity and quality traits of rice under system of rice intensification. Madras Agricultural Journal 99(4-6), 301-304.

Khadka, R.B., Raut, P., 2011. System of Wheat Intensification
(SWI): A new concept on low input technology for increasing wheat yield in marginal land. Mercy Crops Nepal. Available from http://sri.ciifad.cornell.edu/ countries/nepal/Nepal_SWI_Khadka11.pdf.

Misra, S.K., Singh, V., Pareek, S.K., Singh, V., 2002. Standardization of propogation techniques in asparagus. Annals of Agricultural Research 23(4), 608-610.

Mondal, S., Bauri, A., Pramanik, K., Ghosh, M., Malik, G.C., Gosh, D.C., 2013. Growth, Productivity and Economics of Hybrid Rice as Influenced by Fertility Level and Plant Density. International Journal of Bio-resource and Stress Management 4(4), 547-554.

Rasmussen, I.S., Dresboll, D.B., Kristensen, K.T., 2015. Winter wheat cultivars and nitrogen $(\mathrm{N})$ fertilization - Effects on root growth, $\mathrm{N}$ uptake efficiency and $\mathrm{N}$ use efficiency. European Journal of Agronomy 68, 38-49.

Suryawanshi, P.K., Patel, J.B., Kumbhar, N.M., 2013. Yield and economics of wheat (Triticum aestivum L.) influence by SWI techniques with varying nitrogen levels. International Journal of Agricultural Sciences 9(1), 305-308.

Thakur, A.K., Rath, S., Roychowdhury, S., Uphoff, N., 2010. Comparative performance of rice with system of rice intensification (SRI) and conventional management using different plant spacing. Journal of Agronomy and Crop Science 196(2), 146-159.

Thapa, T., Chaudhary, P., Ghimire, S., 2011. Increasing Household Food Security through System of Wheat Intensification (SWI) Techniques. Mercy Crops Nepal. Available from http://sri.ciifad.cornell.edu/countries/ nepal/Nepal_SWI_Khadka11.pdf .

Watson, D.J., 1952. The physiological basis of variation in yield. Advances in Agronomy 4, 101-144. 